DOI: 10.1515/ausp-2015-0041

\title{
The Question of Identity in Gary Shteyngart's Little Failure
}

\author{
Enikő MAIOR \\ Partium Christian University (Oradea, Romania) \\ Modern Languages Department \\ enikomaior@yahoo.com
}

\begin{abstract}
In my paper I want to deal with the question of identity and Gary Shteyngart's last novel, Little Failure (2014). The novel is a memoir that deals with young Gary's struggle as an individual of Russian Jewish origins trying to accommodate himself to the American way of life. America with its multicultural and multiethnic environment puts the immigrant Gary in a very sensitive position. He does not know how to deal with African Americans; shall he avoid them or run away? Shall he befriend Asian colleagues or not? Are Jewish friends more valuable than others? These are the questions that Gary Shteyngart has to answer and find his own voice. The protagonist of the novel under discussion tries to find his identity which is in continuous change. He tries to figure out in a world filled with cultural, racial and urban conflicts his own identity from the perspective of a former immigrant and as a member of a minority group. The task of my paper is to show how the question of identity has changed and what solution Shteyngart's novel can offer for the protagonist in the process of identity formation.
\end{abstract}

Keywords: identity, Jewish American identity, culture clash

In my paper I will deal with the question of different cultures in Gary Shteyngart's last novel Little Failure (2014). The name of Gary Shteyngart (born 1972) has become widely known since the appearance of his first novel, The Russian Debutante's Handbook (2002). With this novel Gary Shteyngart won the Stephen Crane Award for First Fiction, the Book-of-the-Month Club First Fiction Award and the National Jewish Book Award. The Guardian called it the best debut for 2002, and the New York Times called it a Notable Book. Shout NY Magazine named him one of the five best writers of 2002. I think that this enumeration already answers the question why I started dealing with Gary Shteyngart.

Shteyngart was born in Leningrad (now St. Petersburg) in 1972 as the son of Russian Jewish parents. He moved to the United States at the age of 7 and started learning English. He managed to get rid of his Russian accent only at the age 
of 14. He grew up in a household without a TV set and turned to literature for comfort. His novels heavily rely on the works of the greatest Russian writers of earlier times. He comes from a gigantic empire, Russia. and he is perfectly aware of this. In an interview with Sara Brown and Armando Celayo he said that his newly chosen home is another empire: "Russia - no matter what guise it's under - and America - no matter what guise it's under - will always have these messianic visions" $(2009,31)$. His task as an individual is to find his own identity in these two different worlds with messianic visions. Shteyngart cannot forget about his Russian identity but he has to find his own Russian Jewish American one in the United States of America.

The term 'identity' started to play an important role in the 1960s with the emergence of different minority groups. There are several interpretations of the term "identity," but all agree on one thing: that it is a complex and highly variable process. I will largely rely on the findings of social psychology and education in my definitions. Roger Brown in his work Social Psychology says, "identity is a concept no one has defined with precision, but it seems we can move ahead anyway because everyone roughly understands what it means" (1986, 551).

In the case of Jewish identity, the notion of "identity" refers to the objective signs of Jewishness as perceived by both the Jews themselves and the rest of the given community. Individual identity is made up of the following elements: social class, physical appearance, religion, traditions, habits, language and ethnic belonging. As Ester and Rudi Reisel say in their work Modern Jewish Identity: A Rationalistic Motivation for Remaining Jewish, "The trauma of the Jews, deriving from the threat to their security and the cumulative fears of the danger of persecution that were part of their lives down through the generations, taught them to learn from their history and became an inseparable part of their unique identity" $(2000,167)$. History, the environment in which they lived, and their ability to adapt to all the given circumstances add flavor to their identity formation. They were and are influenced by their environment and they have an influence on their environment.

Generally speaking, by identity we often mean both identification and selfawareness. If we take the former as its principal meaning, it is nothing else but the borrowing of identity from someone else or a distinct community; thus we are dealing here with the fusion of one's identity with someone else's, or an uncritical acceptance of social expectations. In more precise terms, if an individual is a member of a larger community, s/he almost unconsciously tries to absorb and adjust to the norms of that particular group. The obvious aim is to shape himself or herself according to that community's expectations. But, if we consider the second meaning of identity, we are bound to realize that it also implies selfawareness; that is, the individual's apprehension of him/herself as an individual and also of his/her relation to the world. In this latter case, the subject is likely 
to see and appraise himself from a quasi-external vantage point. Hence, in the present context of literary analysis, it will be both convenient and expedient to use "identity" as a close synonym for "social identity," because identity is, after all, the way you perceive your relative position and rank - i.e. your status - in the social hierarchy.

However, the self as such cannot and probably must not be purely personal. Without the realization of social and cultural circumstances and their consideration, a personal self cannot come into being. Moreover, it is impossible to think of self as something constant: instead, it is a kind of fluid and dynamic entity that is always in motion, in a relative flux, owing to the factors that actually shape it.

The construction of social identity is indispensable for the maintenance of the self. Manfred Pütz argues that "self-definition involves interactions between world and self and individuals among each other" $(1979,30)$. Here the notion of search for a self becomes synonymous either with construction or assumption: searching for a self is nothing else but the building-up or the choosing of one. People are made to face a series of adversities even in the minor details of their everyday lives, and one main determining factor in their choices is what ingroup priorities (formulated as codes) dictate. To find one's self-awareness, one has to cope with obstacles, such as those of self-evaluation, self-conception or self-perception. According to Ferenc Pataki, we can say that the construction of self-definition is the result of an on-going series of transactions between self and community and of repeated attempts in a long process whereby one's self perceives information drawn from experiences of one's own, and evaluates them and himself/herself accordingly (1982, 56).

Identity is a predominantly socio-cultural construction: the individual is ultimately incapable of defining him/herself in terms other than social. This also means that identity is far from being a private business of the subject. The process of searching for an identity is bound to be complex and ambiguous. On the one hand, it can signify a search for identification: search for an identifiable role, for a time-tested mode of conduct, for an approved code of behavior in a group, as we find out from Duncan Mitchell's A Dictionary of Sociology (1968). On the other hand, it can mean search for self-awareness as well. However, it is obvious that these two meanings are linked: we can safely claim that an individual, in the course of trying to find a self-definition, assumes roles and puts on masks to find his/her real self in the end. This is the way the philosopher Erik Erikson sees it: "the process of reaching self-awareness is [...] a series of attempts of roles" (qtd. in Atkinson 1997, 376). The takeover of roles makes man fit into society: "to create and to take over roles [...] supply the individual with forms of social identity” (Pütz 1979, 52).

Social identity is fluid; it is a changing dynamic, always in motion with fixed statuses. These fixed statuses are the roles people fulfill in life, as Pütz 
explains, "an individual moves or fails between fixed points of reference" (1979, 30). Hence, when one searches for self-awareness, one is looking for something constant in one's life: permanence equals security. Nevertheless, personal identity is unthinkable without social identity, which is in constant motion - personal identity is not rigid, either. However, once found, its bases are more or less founded; but due to the constant external pressures, it is not stable. When one is able to step over the limitations of the group, that is, when one defines oneself in one's own terms, that is the beginning of self-realization. The conditions for this are not those of the group anymore, but one's own expectations of oneself.

Social identity involves the putting on of masks, faces, social roles, ways in which the persona builds up him/herself to respond to the in-group community and satisfy the impulses from the surrounding environment. But, with social identity, you are not given the chance to elaborate your own self: it is the social context that decides how worthy you are to people. Ferenc Pataki describes this process as the qualifying transactions of the social environment $(1982,59)$. According to this evaluation, you step into roles in the community, you identify yourself with this or that label/mask/role/status, as if testing who you are, and what your limits are. At this point, the notion of stereotyping enters the picture: certain stereotypes are associated with particular kinds of people who are unable to break out of these labels (Virágos and Varró 2002, 8). Roles demand a given code of behavior and you must respect the rules of the game, otherwise you are likely to be rejected by the group.

We can say that this construction is the result of a long learning process, wherein external factors are indispensable. These factors are present as constant pressures on one's consciousness. In a way, when one finally defines one's own self, one does not do more than choose from the alternatives that the circles of loyalty offer. This self-identity or personal identity is your own image of yourself: like a mental test so as to find who you are in reality. Personal identity is formed as an answer to an ethical and cultural context. At the same time, it is never something precise. Victoria Aaron says in her work A Measure of Memory:

The individual cannot be separated ultimately from the historical or cultural context that, however unconsciously, informs his or her preoccupations. Bearing witness must also then become a process of personalizing history, of finding personal moral significance in the idea of preserved Jewish sensibility or of finding apparent opportunities for its denial in the idea of its ultimate loss. $(1996,9)$

On the old continent the Jews were able to define their own identities within the boundaries of their communities. As they were living in communities set apart from the majority, the question of identity and the quest for identity did 
not play an important role. But in America their need for a communal identity was not satisfied in most of the cases. This does not apply to those Jews living in Hasidic communities where the question of individual identity still does not play an important role. The rabbi decides on the role of each member of the congregation or community and they have to comply with their assigned role.

Uzi Rebhun in the Encyclopedia of the Jewish Diaspora: Origins, Experiences, and Culture, volume 2, says,

Jewish identificational patterns must be transfigured, but a strong and coherent attachment to the Jewish heritage must maintain its distinctiveness from other faiths. The legitimacy of ethnic and religious differences, which is part of the ethos of today's multicultural United States, must turn these complicated challenges into new opportunities to ensure the strength and long-standing vitality of the American Jewish Diaspora. (2009, 591)

We can no longer speak about a religious community of the Jews but we cannot overlook its heritage to the coming generations. Being Jewish has become a question of willingness rather than a question of belonging to a different religious group.

Nathan Rotenstreich in his work entitled Identification and Identity speaks about

the internalization of identity or the ongoing erosion of the semi-objective components of that identity [...] Since the reality surrounding the Jews in the West is more and more of a universal character, the particularity of Jewish existence becomes more and more contracted and perhaps vis-àvis the pattern of universality and particularity, the patters of universality proper and individuality will be retained. $(1993,54)$

In the case of the American Jews the question of individual identity will be the most important idea.

It is also necessary to speak about Russian Jews and Jewishness as it represents a different kind of identification pattern. During the Soviet era it became widely accepted to view it as something rooted in ethnicity. It is totally severed from religion and religious beliefs.

This means that Jewishness is understood as a primordial (rather than a constructed) category. For Russian Jews, biology is destiny, and neither conversion to Christianity nor complete identification with Russian culture will change it. Jews are seen as fundamentally - i.e. biologically - different. (Gershenson 2008, 176) 
I think it is important to understand how Russian Jews view themselves in order to understand the identity constructed in the works of Gary Shteyngart. This is a totally different kind of Jewish identity which is based on biology, thus lacks real content, which might lead to its disappearance. It is also important to mention that for Russian Jews it was a necessity: to develop the intellectual, to keep close contact with their fellow ethnic brothers and to form a resistance group against the Soviet political system. There is also "a particular type of Jewish humour as well as a playful and verbose use of language" (Gershenson 2008, 177). This specific type of humour can be found in the works of the writer under discussion. I think it is necessary to see clearly how the question of identity is tackled by the Russian Jews in decoding Shteyngart's novels.

We can call Gary Shteyngart a Russian Jewish American writer. In his book Out of Russia (2011) Adrian Wanner considers that Shteyngart's Russianness started to play a role after leaving Russia. As we could see above, identity is formed as the result of a long learning process that is influenced by external factors. So Shteyngart's childhood environment, language and culture play an important role in his own self-representation. His first language to learn was Russian and in the beginning he felt alienated in America. In an interview he remembers: "[...] the Russian language is my friend. It's comfortable around me. It knows things the noisy brats around me, who laugh and point as I intone my Slavic sibilants, will never understand [...] All this the great and mighty Russian language knows. All this it whispers to me at night, as I lie haunted by childhood insomnia" $(2004,6)$.

As for his acceptance in Russia as a Russian writer he said, "Yeah, nobody cares. It's a large society. I have friends who I visit that are nice people. It's just a very stressful society because half of its economy collapsed [...] To grow up in this kind of environment is incredibly stressful, incredibly depressing" (quoted in Brown 1986, 32). His identity has been influenced by his country of origin. I agree with Adrian Wanner who speaks about a new type of emerging writers who belong to a so-called "translingual diaspora literature" (2011,3). Shteyngart's identity is the result of a long process which was and is still influenced by his being born in Russia, by his ethnic belonging, which puts him into a different position and by embracing his host or accepted country, America. Shteyngart is Jewish because he was born one, his ethnic belonging links him to an ethnic group, but this does not mean that he follows Jewish rituals and traditions. He is not an observant Jew living according to the covenant with God. However, he is fully aware of his belonging to this ethnic group. The Jews were able to accommodate themselves much more easily than any other ethnic group to the hardships of life because of their long history of persecution and survival. For Jews the most important thing was to study and this is how Gary Shteyngart, the Jewish Russian immigrant, succeeds in life at an age when to deal with life is already very hard. As his parents refused to speak English in their household and they did not have 
a television set, it was difficult for Shteyngart to find a common language with his colleagues at school: "So I find myself doubly handicapped, living in a world where I speak neither the actual language, English, nor the second and almost just as important language - television" $(2004,7)$. His estrangement is heightened by his being very poor and wearing old fashioned clothes. He turns to writing in English so as to heal himself and to find remedy :

Around this time, I start writing in English with gusto. I write for the same reasons other curious children write: loneliness, boredom, the transgressive excitement of building your own world out of letters, a world not sanctioned by family and school... Thousands of sacrilegious English words pour out in a matter of days, words that aren't inflected with my still-heavy Russian accent. Impatiently, I blow on passages deleted with white-out, knowing somehow that my life is about to change. And it does [...] it helps me cross the line from unclubbable fruitcake to tolerated eccentric. Tell me, is there anything writing can't do? $(2004,7-8)$

Shteyngart's ardent wish to get assimilated into the mainstream American way of life culminates in the buying of a Sony Trinitron television set which after being turned on would not be turned off for the next ten years. This way he becomes a member of the American society, spending most of his free time watching television instead of writing. He says, "I become a naturalized citizen of this country" $(2004,8)$. Finally he has taken on the habits of other Americans and is on his way to fulfilling the American dream.

The Soviet Union's fragile historical perspectives, its economic uncertainties, and the open anti-Semitism manifested in several pockets of the Russian civilization forced thousands of Russian Jews to leave the country behind in search of more promising alternatives of existence. America, with its apparently unlimited resources, became one of the most attractive destinations for those seeking a safe haven for themselves and their progeny. Despite periodical restrictions, American society was open to immigration, and ready to absorb - in the words of Emma Lazarus - "the homeless" and the "tempest-tossed" (quoted in Hollander 2005). As she epitomized the essence of the notion of refugees seeking a haven in her famous sonnet to be read on the inner wall of the Statue of Liberty,

Give me your tired, your poor,

Your huddled masses yearning to breathe free,

The wretched refuse of your teeming shore.

I lift my lamp beside the golden door! (Hollander 2005) 
In his memoir Shteyngart tells his story from his early childhood spent in Leningrad to his arrival and accommodation to the American reality. The hero of the memoir, little Igor and later Gary somehow tries to figure out who he is in this new multicultural world. He arrives in America, in New York to find himself in an alien world. Moreover, he finds himself among "the enemy." Little Igor used to be an asthmatic child who was afraid of everything as it can be seen on a picture from the book. Shteyngart says:

I am scared of the photo studio. I am scared of the telephone. Scared of anything outside our apartment. Scared of the people in their big fur hats. Scared of the snow. Scared of the cold. Scared of the heat. Scared of the ceiling fan at which I would point one tragic finger and start weeping. Scared of any height higher than my sickbed. Scared of Uncle Electric Current. "Why was I so scared of everything?" I ask my mother nearly forty years later. "Because you were born a Jewish person," she says. $(2014,25)$

Could this fear be something genetically encoded? Or is it only the fear of an individual who happens to be of Jewish origins and tries to find his place in the world?

After his arrival in the U.S., Gary has to face another enemy, which is the multicultural society. The so-called American melting pot with its thousand faces scares the young boy. He soon learns that he has to avoid dark-skinned people because they are all criminal. He thus also experiences a new feeling that of being white:

There's hatred and fear, sure, but just a little down the line, laughter and relief. The happy recognition that, as unemployed and clueless as we are, there is a reservoir of disgust in our new homeland for someone other than ourselves. We are refugees and even Jews, which in the Soviet Union never won you any favors, but we are also something we never really had the chance to appreciate back home. We are white. $(2014,109)$

He learns that being black or Spanish is worse than being an immigrant. As he is white, he cannot be discovered and his disguise is perfect.

By the end of the novel Shteyngart has reached the final destination of each immigrant of accepting and liking himself as an American of Russian Jewish origins. 


\section{Works cited}

Aarons, Victoria. 1996. A Measure of Memory. Athens and London: The U of Georgia P.

Atkinson, Rita L., et al. 1997. Pszichológia. [Introduction to Psychology.] Trans. Bodor et al. Budapest: Osiris.

Brown, Roger. 1986. Social Psychology. The Second Edition. New York: The Free P. Brown, Sara and Armando Celayo. 2009. "I am the World, I'll Eat the World." World Literature Today (March-April): 29-32.

http://www.jstor.org/stable/20621529 (18 Jan. 2013)

Gershenson, Olga. 2008. Ambivalence and Identity in Russian Jewish Cinema. Jewish Cultural Studies Volume One: Jewishness: Expression, Identity, and Representation, ed. Simon J. Bronner, 175-194. Oxford: The Littman Library of Jewish Civilization.

Gershenson, Olga and David Shneer. 2011. Soviet Jewishness and Cultural Studies. Journal of Jewish Identities vol. 4. no.1: 129-146.

http://muse.jhu.edu/journals/jji/summary/v004/4.1.gershenson.html (23 Jan. 2013)

Goldberg, David Theo and Michael Krausz eds. 1993. Jewish Identity. Philadelphia: Temple UP.

Grinberg, Natasha. “Can’t Live Long Without Writing.” Del Sol Literary Dialogues. http://www.webdelsol.com/Literary_Dialogues/interview-wds-shteyngart.htm (06 March 2013)

Hollander, John. ed. 2005. Emma Lazarus: Selected Poems. New York: The Library of America.

Mitchell, G. Duncan, ed. 1968. A Dictionary of Sociology. London: Routledge.

Pataki Ferenc. 1982. Az én és a társadalmi azonosságtudat. [The I and the Social Conciousness.] Budapest: Kossuth.

Penkower, Monty Noam. 2010. Twentieth-Century Jews: Forging Identity in the Land of Promise and in the Promised Land. Boston: Academic Studies P.

Pickering, Michael. 2001. Stereotyping: The Politics of Representation. New York: Palgrave.

Price, Leah ed. 2011. Unpacking my Library: Writers and their Books. New Haven and London: Yale U. P.

Pütz, Manfred. 1979. The Story of Identity: American Fiction of the Sixties. Stuttgart: Metzler.

Raphael, Marc Lee. 2003. Judaism in America. New York: Columbia UP.

Reisel, Ester and Rudi Reisel. 2000. Modern Jewish Identity: A Rationalistic Motivation for Remaining Jewish. Jerusalim: Gefen Publishing House.

Rovner, Adam. 2006. So Easily Assimilated: The New Immigrant Chic. AJS Review vol. 30. no. 2: 314-24. 
Ryan, Karen. 2012. Out of Russia: Fictions of a New Translingual Diaspora by Adrian Wanner Review. Slavic Review vol. 71. no. 3: 719-720. http://www.jstor.org/stable/10.5612/slavicreview.71.3.0719 (21 January 2013)

Rycroft, Charles. 1979. A Critical Dictionary of Psychoanalysis. New York: Penguin.

Schapiro, Barbara Ann. 1994. Literature and the Relational Self. New York: New York UP.

Shteyngart, Gary. 2002. The Russian Debutante's Handbook. London, Berlin, New York and Sydney: Bloomsbury Publishing.

---. 2004. The Mother Tongue between Two Slices of Rye. The Threepenny Review no. 97: 5-8. http://www.jstor.org/stable/4385311 (06 March 2013)

---. 2014. Little Failure. New York: Random House Trade Paperbacks.

Theodorson, George A. and Achilles G. Theodorson. 1969. A Modern Dictionary of Sociology. New York: Thomas Y. Crowell Company.

Virágos Zsolt, and Gabriella Varró. 2002. Jim Crow örökösei. [The Heirs of Jim Crow.] Budapest: Eötvös.

Wanner, Adrian. 2011. Out of Russia. Evanston, Illinois: Northwestern UP. 